\title{
Crystal Structure of 4-Ethoxy- $N$-(o-hydroxyacetophenolidene)aniline
}

\author{
Muhittin AYGÜN, ${ }^{* \dagger}$ Nilgün AKKUŞ,** Kutalmş GüVEN, ${ }^{* * *}$ and Kadir AKGÜNGöR* \\ *Department of Physics, Faculty of Art and Sciences, Dokuz Eylul University, 35150-İzmir, Turkey \\ **Department of Physics, Faculty of Art and Sciences, Ylldiz Technical University, 80270-Istanbul, Turkey \\ ***Department of Chemistry, Faculty of Art and Sciences, Kırıkkale University, 71450-Kırtkkale, Turkey
}

\begin{abstract}
The title compound, $\mathrm{C}_{16} \mathrm{H}_{17} \mathrm{NO}_{2}$, was found to crystallize in the triclinic space group $P \overline{1}$. The unit cell parameters are: $a=$ 8.279(1) $\mathrm{A}, b=14.843(2) \AA, c=5.959(1) \AA, \alpha=97.02(1)^{\circ}, \beta=102.75(1)^{\circ}, \gamma=100.52(1)^{\circ} ; Z=2$. The molecule is not planar. The ethoxy group is almost coplanar with the ethoxyphenyl ring, the hydroxy group and the central moiety of the molecule are almost in the hydroxyphenyl ring plane. The dihedral angle between the two planes is $65.4(1)^{\circ}$. The crystal structure is stabilized by weak intermolecular interactions of the $\mathrm{C}-\mathrm{H} \cdots \mathrm{O}$ type.
\end{abstract}

(Received February 6, 2003; Accepted June 23, 2003; Published on web October 15, 2003)

In this paper we present the crystal and molecular structures of a Schiff's base, $\mathrm{C}_{16} \mathrm{H}_{17} \mathrm{NO}_{2}$. The important place held in organic chemistry by Schiff's base ligands has been confirmed by surveys which are continuously being made. Also, since organometallic compounds exhibit conductivity and magnetic properties due to one or more metal atoms introduced into the Schiff's bases, their synthesis is becoming a object of growing interest. It is known that such substances are used in cancer research $^{1}$ and in the industry due to liquid-crystal characteristics. $^{2}$

The 4-ethoxy- $N$-(o-hydroxyacetophenolidene)aniline was prepared by adding $p$-ethoxyaniline to the 2hydroxyacetophenone (1:1 molar ratio) in hot dry ethanol. The reaction mixture was cooled and filtered. Upon concentration and cooling, the ligand separated out. Subsequently, the ligand was recrystallized from ethanol.

The crystal and molecular structures of $\mathrm{C}_{16} \mathrm{H}_{17} \mathrm{NO}_{2}$ were determined by single-crystal $\mathrm{X}$-ray diffraction. The crystal data, details of the data collection and the structure determination are given in Table 1. The structure was solved by direct methods and refined by full-matrix least squares on $F^{2}$. The nonhydrogen atoms were refined anisotropycally. The $\mathrm{H}$ atoms were located from difference maps and refined isotropically. The $\mathrm{C}-\mathrm{H}$ bond distances are $0.90(2)$ to $1.04(4) \AA$, while $U_{\mathrm{eq}}$ values for the $\mathrm{H}$ atoms are in the range of $0.073(7)-0.15(1) \AA .{ }^{2}$ The refined atomic parameters with equivalent isotropic

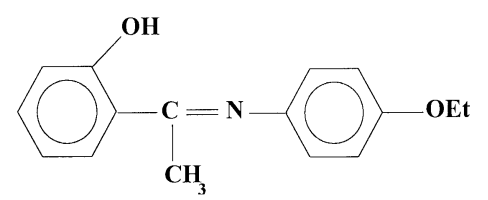

Fig. 1 Chemical diagram of the title compound

† To whom correspondence should be addressed.

E-mail: muhittin.aygun@deu.edu.tr temperature factors for non-hydrogen atoms are given in Table 2. The bond lengths and angles are given in Table 3 .

The molecular structure of the title compound is shown in Fig. 2. The N1=C9 double bond, with a length of $1.287(4) \AA$, is slightly longer than another similar Schiff's base ${ }^{3}\left[\mathrm{C}_{19} \mathrm{H}_{18} \mathrm{ON}_{2}\right.$, $1.268(2) \AA]$. The ethoxy group is almost coplanar with the ethoxyphenyl ring, the maximum deviation from the plane being 0.034(4)A for the $\mathrm{C} 1$ atom. The hydroxy group and the

Table 1 Crystal and experimental data

Formula: $\mathrm{C}_{16} \mathrm{H}_{17} \mathrm{NO}_{2}$
Formula weight: 255.31
Crystal system: triclinic
Space group: $P \overline{1} \quad Z=2$
$T=293(2) \mathrm{K}$
$a=8.279(1) \AA$
$b=14.843(2) \AA$
$c=5.959(1) \AA$
$\alpha=97.02(1)^{\circ}$
$\beta=102.75(1)^{\circ}$
$\gamma=100.52(1)^{\circ}$
$V=692.1(2) \AA^{3}$
$D_{\text {calc }}=1.225 \mathrm{~g} \mathrm{~cm}^{-3}$
$\mu\left(\right.$ Mo $\left.\mathrm{K}_{\alpha}\right)=0.8 \mathrm{~cm}^{-1}$
Radiation: Mo $\mathrm{K}_{\alpha}(=0.71073 \AA)$
Reflection collected/unique: $2829 / 2639$
Independent reflection: $[I>2 \sigma(I)] 1186$
Number of parameters: 241
$R=0.041$
wR $=0.12$
$(\Delta / \sigma)_{\max }=0.000$
$(\Delta \rho)_{\max }=0.12 \mathrm{eA}^{-3}$
$(\Delta \rho)_{\min }=-0.16 \mathrm{eA}^{-3}$
Measurement: Rigaku AFC-7S
Program system: MSC/AFC Diffractometer Control Software
Structure determination: direct method with SHELXS-97
Refinement: full matrix least-squares with SHELXL-97 in
$\quad$ WINGX


Table 2 Final atomic coordinates and equivalent isotropic temperature factors $\left(\AA^{2}\right)$ for the non-H atoms

\begin{tabular}{ccccl}
\hline Atom & $x$ & $y$ & $z$ & \multicolumn{1}{c}{$U_{\text {eq }}$} \\
\hline O1 & $0.0589(3)$ & $0.4017(1)$ & $0.2073(3)$ & $0.0981(9)$ \\
O2 & $0.6035(2)$ & $0.0880(1)$ & $0.8431(3)$ & $0.0761(6)$ \\
N1 & $0.1323(3)$ & $0.2936(1)$ & $0.4971(3)$ & $0.0719(7)$ \\
C1 & $0.8190(5)$ & $0.0433(2)$ & $1.1086(7)$ & $0.0933(12)$ \\
C2 & $0.7002(4)$ & $0.1073(2)$ & $1.0802(5)$ & $0.0779(10)$ \\
C3 & $0.4904(3)$ & $0.1425(2)$ & $0.7726(4)$ & $0.0666(8)$ \\
C4 & $0.4007(3)$ & $0.1201(2)$ & $0.5403(4)$ & $0.0755(10)$ \\
C5 & $0.2850(4)$ & $0.1705(2)$ & $0.4529(5)$ & $0.0752(9)$ \\
C6 & $0.2520(3)$ & $0.2425(2)$ & $0.5946(4)$ & $0.0672(8)$ \\
C7 & $0.3440(3)$ & $0.2651(2)$ & $0.8250(4)$ & $0.0749(10)$ \\
C8 & $0.4636(3)$ & $0.2162(2)$ & $0.9143(5)$ & $0.0732(9)$ \\
C9 & $-0.0087(3)$ & $0.2910(1)$ & $0.5562(3)$ & $0.0634(8)$ \\
C10 & $-0.1219(3)$ & $0.3489(2)$ & $0.4514(3)$ & $0.0654(8)$ \\
C11 & $-0.0837(4)$ & $0.4011(2)$ & $0.2814(4)$ & $0.0771(10)$ \\
C12 & $-0.1957(6)$ & $0.4550(2)$ & $0.1845(5)$ & $0.0980(13)$ \\
C13 & $-0.3400(6)$ & $0.4569(2)$ & $0.2568(6)$ & $0.0989(13)$ \\
C14 & $-0.3814(5)$ & $0.4069(2)$ & $0.4225(5)$ & $0.0892(10)$ \\
C15 & $-0.2730(4)$ & $0.3538(2)$ & $0.5170(5)$ & $0.0760(10)$ \\
C16 & $-0.0651(5)$ & $0.2297(2)$ & $0.7202(6)$ & $0.0773(11)$ \\
\hline
\end{tabular}

$U_{\text {eq }}=(1 / 3) \sum_{i} \Sigma_{j} U_{i j} a_{i}^{*} a_{j}^{*}\left(\boldsymbol{a}_{i} \cdot \boldsymbol{a}_{j}\right)$

Table 3 Selected bond lengths $(\AA)$ and bond angles $\left(^{\circ}\right)$ for $\mathrm{C}_{16} \mathrm{H}_{17} \mathrm{NO}_{2}$

\begin{tabular}{llll}
\hline $\mathrm{O} 1-\mathrm{C} 11$ & $1.348(4)$ & $\mathrm{C} 2-\mathrm{O} 2-\mathrm{C} 3$ & $118.6(2)$ \\
$\mathrm{O} 2-\mathrm{C} 2$ & $1.427(3)$ & $\mathrm{C} 11-\mathrm{O} 1-\mathrm{H} 1$ & $109.6(17)$ \\
$\mathrm{O} 2-\mathrm{C} 3$ & $1.376(3)$ & $\mathrm{C} 6-\mathrm{N} 1-\mathrm{C} 9$ & $122.0(2)$ \\
$\mathrm{O} 1-\mathrm{H} 1$ & $0.93(3)$ & $\mathrm{O} 2-\mathrm{C} 2-\mathrm{C} 1$ & $108.2(3)$ \\
$\mathrm{N} 1-\mathrm{C} 6$ & $1.423(3)$ & $\mathrm{O} 2-\mathrm{C} 3-\mathrm{C} 4$ & $115.6(2)$ \\
$\mathrm{N} 1-\mathrm{C} 9$ & $1.287(4)$ & $\mathrm{O} 2-\mathrm{C} 3-\mathrm{C} 8$ & $124.8(2)$ \\
$\mathrm{C} 1-\mathrm{C} 2$ & $1.485(5)$ & $\mathrm{N} 1-\mathrm{C} 6-\mathrm{C} 7$ & $122.3(2)$ \\
$\mathrm{C} 9-\mathrm{C} 10$ & $1.474(3)$ & $\mathrm{N} 1-\mathrm{C} 9-\mathrm{C} 16$ & $123.2(2)$ \\
$\mathrm{C} 9-\mathrm{C} 16$ & $1.505(4)$ & $\mathrm{C} 10-\mathrm{C} 9-\mathrm{C} 16$ & $118.9(2)$ \\
& & $\mathrm{N} 1-\mathrm{C} 9-\mathrm{C} 10$ & $118.0(2)$ \\
& & $\mathrm{O} 1-\mathrm{C} 11-\mathrm{C} 12$ & $118.3(3)$ \\
\hline
\end{tabular}

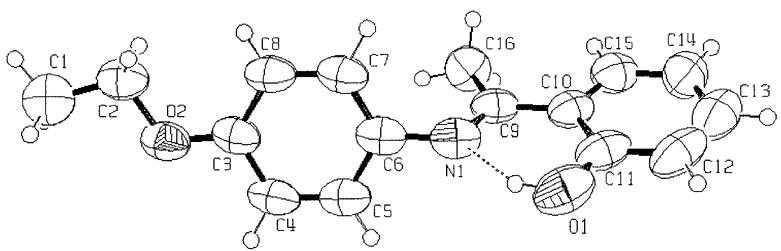

Fig. 2 Molecular structure of the title compound along with the labeling scheme for non-H atoms. Displacement ellipsoids are shown at the $50 \%$ probability levels; $\mathrm{H}$ atoms are drawn as small circles of arbitrary radii. The intramolecular hydrogen bond is shown as a dashed line.

central moiety of the molecule are almost in the hydroxyphenyl ring plane, the maximum deviation from the plane being $-0.139(3) \AA$ for the $\mathrm{C} 16$ atom. The dihedral angle between the two planes is $65.4(1)^{\circ}$. The crystal structure is stabilized by one

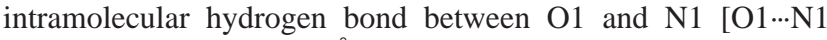

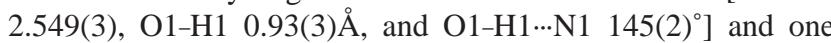
weak intermolecular interaction between $\mathrm{C} 16$ and $\mathrm{O} 1^{\mathrm{i}}[\mathrm{C} 16 \cdots \mathrm{O} 1$ 3.452(4), $\mathrm{C} 16-\mathrm{H} 0.97(3) \AA$ and $\mathrm{C}-\mathrm{H} \cdots \mathrm{O} 1^{\mathrm{i}} 156(3)^{\circ}$; symmetry code: (i) $x, y, 1+z]$.

\section{References}

1. E. Hodnett, M. Dunn, and J. William, J. Med. Chem., 1970, 13:4, 768 .

2. K. Nishijima, T. Nozaki, H. Miyasaka, G. Mago, N. Matsumoto, and H. Okawa, Inorg. Chim. Acta, 1995, 234, 131.

3. M. Aygün, Ş. Işık, Z. Turgut, S. Özbey, E. Kendi, Acta Cryst., 1999, C55, 1689.

4. L. J. Farrugia, WINGX, Crystallographic Programs for Windows 2000, 1999, University of Glasgow, Scotland. 